\title{
Biological control of invasive Dryocosmus kuriphilus with introduced parasitoid Torymus sinensis in Croatia, Slovenia and Hungary
}

\author{
DINKA MATOŠEVIĆ ${ }^{1}$ \\ NIKOLA LACKOVIĆ ${ }^{1}$ \\ GEORGE MELIKA ${ }^{2}$ \\ KATARINA KOS ${ }^{3}$ \\ IVA FRANIĆ \\ ÉVA KRISTON2 \\ MIKLÓS BOZSÓ2 \\ GABRIJEL SELJAK ${ }^{4}$ \\ MOJCA ROT ${ }^{4}$ \\ ${ }^{1}$ Department for forest protection \\ Croatian Forest Research Institute \\ Jastrebarsko, Croatia \\ 2 Plant Health and Molecular Biology Laboratory \\ National Food Chain Safety Office, Budapest \\ Hungary \\ ${ }^{3}$ Department of Agronomy, Biotechnical Faculty \\ University of Ljubljana, Ljubljana, Slovenia \\ ${ }^{4}$ Slovenian Agriculture and Forestry Institute \\ Nova Gorica, Department for Plant Protection \\ Nova Gorica, Slovenia \\ ${ }^{5}$ Zagreb, Croatia
}

\section{Correspondence:}

Dinka Matošević

dinkam@sumins.hr

Key words: Torymus sinensis, sweet chestnut gall wasp, parasitoid rearing and release, invasive species, biocontrol

Received July 1, 2015

Revised October 16, 2015.

Accepted January 19, 2016.

\begin{abstract}
Background and purpose: Dryocosmus kuriphilus is considered as one of the major pests of sweet chestnut and the effective method of controlling its populations and damage is the biological control with its introduced parasitoid Torymus sinensis. T. sinensis is a univoltine, host specific parasitoid, phenologically synchronized and morphologically adapted to D. kuriphilus. It has a good dispersal ability, it builds up populations quickly and it effectively controls the pest already few years after the release. In this paper we describe the first results of the introduction and release of $\mathrm{T}$. sinensis for controlling the populations of invasive D. kuriphilus in sweet chestnut forests and orchards in Croatia, Hungary and Slovenia.
\end{abstract}

Materials and methods: Withered D. kuriphilus galls with T. sinensis larvae were collected in Torino vicinities, Italy, in March 2014 and March 2015. After emergence, males and females were put together, kept at $14^{\circ} \mathrm{C}$ and fed with liquid honey until the release. To confirm the establishment of the population of $\mathrm{T}$. sinensis on release site from 2014 in Croatia morphological and DNA identification were used. Fresh galls from the release site of Pazin, Croatia were collected in spring 2015 and parasitism rates of $\mathrm{T}$. sinensis were calculated.

Results and conclusions: In total 10,590 females and 5,295 males of T. sinensis were released in sweet chestnut forests in Croatia, Hungary and Slovenia in 2014 and 2015. The minimum release number of $\mathrm{T}$. sinensis was 100 females $/ 50$ males and the maximum was 1,200 females per site. Subsequent releases with a larger number of females (1,200 and 800 in two years) resulted in a rapid establishment of the population of $\mathrm{T}$. sinensis and parasitism rates of $76 \%$ only one year after the first release was done. The establishment of the population of $\mathrm{T}$. sinensis was confirmed with molecular analyses and morphological identification. Obtained haplotype sequences of $\mathrm{T}$. sinensis have shown similarities with Torymus beneficus. Prior to the release of $\mathrm{T}$. sinensis, all advantages and disadvantages of the introduction of this alien biocontrol species into natural stands in Croatia, Hungary and Slovenia have been considered.

\section{INTRODUCTION}

$A$ ccidental introductions of alien insect species to Europe have become Amore and more frequent in recent decades $(1,2,3)$. Dryocosmus kuriphilus Yasumatsu (Hymenoptera; Cynipidae), an invasive insect pest on sweet chestnut (Castanea spp.) has rapidly spread throughout Europe 
since the introduction to Italy in $2002(4,5,6)$. It is considered as one of the major pests on sweet chestnut, causing yield losses up to $80 \%$ (5). In its native range in China, $D$. kuriphilus populations are kept at low, non-damaging levels by natural enemies $(7,8,9)$. This is not the case in the invaded countries (Japan, South Korea, the USA, Italy, Slovenia, Croatia, Hungary and France) where the indigenous parasitoids have already shifted onto the new host but their parasitism rates are low and have little influence on the population density of their host $(7,8,10,11,12$, 13). Torymus sinensis Kamijo (Hymenoptera: Torymidae) is a parasitoid coming from China like its host and has been proven to be the only effective method of controlling the populations of D. kuriphilus. This specific parasitoid has been successfully introduced to Japan, the USA, Italy and France and used in classical biological control and it has reduced the populations of D. kuriphilus to tolerable levels (infestation less than 30\%) $(6,14,15,16,17,18$,). Adults of $T$. sinensis emerge from withered galls in early spring and, after mating, females lay eggs into newly formed galls, either onto the body surface of the host larva or on the wall of the larval chamber. The parasitoid larva feeds ectoparasitically on the pest's mature larva and pupates during late winter (6). T. sinensis is univoltine, host specific parasitoid, phenologically synchronized and morphologically adapted to $D$. kuriphilus. It has good dispersal abilities, it builds up populations quickly and it effectively controls the pest already few years after the release $(6,17)$. In Italy, on sites with releases of T. sinensis in 2005 and 2006, in 6-7 years parasitism rates have reached on average $67 \%$ (up to $95 \%$ in some sites (17)). All these traits influence the host populations and reduce the number of galls and the damage to tolerable levels.

Studies of native parasitoids have shown that $D$. kuriphilus has recruited a number of oak gall wasp generalist parasitoids, among which are several species from the genus Torymus (T. flavipes (Walker), T. geranii (Walker), T. notatus (Walker), T. auratus (Müller)) $(11,12,13,19)$. However, the effectiveness of the native parasitoids is by far not enough to suppress the populations of $D$. kuriphilus and keep them under economic threshold, so the average percentage of parasitism is low, around $2-4.5 \%(12,15)$

The introduction of T. sinensis is one of the successful cases of biological control of highly invasive species $(14,15$, 16, 17). Considering T. sinensis as a valid and successful management option against $D$. kuriphilus, Croatia, Hungary and Slovenia have started to introduce this parasitoid species to native sweet chestnut stands and orchards, evaluating beforehand all the advantages and disadvantages of releasing this "planned biological invasion” to natural forest stands, since T. sinensis is an alien species as well.

The aim of this paper is to present the first results of the introduction and release of $T$. sinensis for controlling the populations of $D$. kuriphilus in sweet chestnut forests and orchards in Croatia, Hungary and Slovenia.

\section{MATERIAL AND METHODS}

\section{Rearing and release}

The same laboratory rearing method of $T$. sinensis was used in Croatia, Slovenia and Hungary. Withered D. kuriphilus galls with $T$. sinensis larvae were collected on $11^{\text {th }}$ March 2014 and $2^{\text {nd }}$ March 2015 in Borgo d'Ale, Piemonte, Italy in a sweet chestnut orchard. More than 12,000 galls were collected. The parasitism rate of T. sinensis in collected galls was more than 90\% (17, G. Bosio, personal communication). After the collection, the galls were stored in the refrigerator at $4^{\circ} \mathrm{C}$, in glass jars with aerated tops, app. 70 galls per jar in the following entomological laboratories: Croatian Forest Research Institute, Plant Health and Molecular Biology Laboratory, National Food Chain Safety Office, Hungary, and Slovenian Agriculture and Forestry Institute Nova Gorica, Department for Plant Protection. On 1 ${ }^{\text {st }}$ April 2014 and $1^{\text {st }}$ April 2015 the galls were taken out from the fridge and were then kept at room temperature $\left(20-22^{\circ} \mathrm{C}, \mathrm{L}: \mathrm{D}\right.$ 12:12) until the emergence of adults. The glass jars were divided in lots, and each lot was taken out in weekly intervals. This has provided us with a constant supply of fresh adults which could be released in the field within few days.

After the emergence, males and females were put into $50 \mathrm{ml}$ plastic centrifuge tubes with plastic tops (10 females and 5 males per tube) and fed with drops of liquid honey. They were kept in a climatic chamber at $14^{\circ} \mathrm{C}(\mathrm{L}: \mathrm{D}$ 12:12) until release, with honey checked and changed every second to fourth day. All the released adults were less than a week old on the day of the release in Croatia and Slovenia and three week old females were also released in Hungary. The sweet chestnuts in the forests and orchards were checked once per week for the development of leaves and galls to determine the optimal gall size and release date for each site. Field releases (Figure 1) were done on $11^{\text {th }}$ April 2014 in Croatia, 26 $6^{\text {th }}$ May 2014 in Hungary, from $16^{\text {th }}$ April to $19^{\text {th }}$ April 2015 in Croatia, from $28^{\text {th }}$ April to $25^{\text {th }}$ May 2015 in Hungary and from $22^{\text {nd }}$ April to $29^{\text {th }}$ April in Slovenia.

To confirm the establishment of the population of $T$. sinensis on release sites from 2014, withered galls were collected in March 2015 (localities shown in Table 1) and stored in rearing cages at room temperature $\left(20-22^{\circ} \mathrm{C}\right)$. After a few days, parasitoid adults emerged. They were stored in alcohol (70\%) and identified morphologically and by means of molecular biology, using a segment of barcode marker described by Folmer et al. (1994) (20).

\section{DNA protocols and identification}

Insect DNA was extracted from 68 specimens (Table 1) using GenEluteTM Mammalian Genomic DNA Kit (Sigma, USA) following the manufacturer's protocol. Amplification was carried out with conventional PCR in $25 \mu \mathrm{l}$ reactions containing $2 \mathrm{mM}$ of $\mathrm{MgCl} 2,100 \mu \mathrm{M}$ of 
Table 1. Locality codes, coordinates and the number of specimens for morphological and molecular identification of Torymus sinensis on sites in Croatia, Italy and Slovenia

\begin{tabular}{|cccc|}
\hline Code & Locality & Coordinates $(\mathrm{X}, \mathrm{Y})$ & Specimens \\
\hline 69 & Croatia, tunel Učka & $45.314274,14.243933$ & 10 \\
71 & Croatia, Ozalj & $45.606554,15.464357$ & 10 \\
72 & Croatia, Samobor & $45.791143,15.672134$ & 10 \\
73 & Croatia,Pazin & $45.233318,13.918450$ & 10 \\
74 & Slovenia, Vrtojba, & $45.913 .980,13.617 .860$ & 10 \\
75 & Italy, Borgo d' Ale & $45.367584,8.053120$ & 10 \\
77 & Slovenia, Ravnica, & $45.973611,13.6875$ & 8 \\
& Nova Gorica & 68 \\
\hline
\end{tabular}

dNTPs (Fermentas, Lithuania), $0,5 \mu \mathrm{M}$ of each primer HCO (20) and 1859F (21), 1U of Taq polymerase (Fermentas) and $2 \mu$ of template DNA. Thermocycling consisted of an initial denaturation step at $94^{\circ} \mathrm{C}(2 \mathrm{~min})$, which was followed by 45 cycles at $94^{\circ} \mathrm{C}(1 \mathrm{~min}), 50^{\circ} \mathrm{C}(1$ $\min 30 \mathrm{~s})$ and $70^{\circ} \mathrm{C}(1 \mathrm{~min} 30 \mathrm{~s})$ and final extension step at $70^{\circ} \mathrm{C}(10 \mathrm{~min})$. All reactions contained a negative control and were checked for amplification by gel electrophoresis. Confirmed products were purified and directly sequenced with $\mathrm{HCO}$ at Macrogen Europe (Amsterdam, Netherlands). The resulting sequences were delivered electronically.

Chromatograms were manually verified and the sequences were aligned using ClustalW algorithm implemented in BioEdit (22). Diversity indices and test of genetic differentiation estimates were calculated using DnaSP (23). Basic local alignment search (BLAST) (24) at NCBI Gene Bank was performed, with the divergence limit for species delimitation calculated according to Meier et al. (2006) (25), using MEGA 6 (26). Haplotype determination was performed using TCS $1.21(27,28)$

\section{Morphological identification and parasitism rates}

For the identification of adult parasitoids, an unpublished key generated by R. R. Askew (Manchester, UK) was used, which has been a basic identification tool in use for decades in the research of parasitoid communities of oak gall wasps. The catalogue of oak gall wasp parasitoids (29) is based exclusively on this key. The part of the key with Torymus species is based mainly on Graham et al. (1998) (30) revision work. The part of the key generated by R.R. Askew for the identification of Torymus species does not include $T$. sinensis, so we added the necessary diagnostic characters for the identification of $T$. sinensis. The adopted key for European Torymus species which attack oak gall wasps and D. kuriphilus is still under revision and will be published later with important notes on $T o$ rymus larvae's morphology.

For parasitism rates, 357 withered D. kuriphilus galls were collected in February 2015 in Pazin, Croatia (release site from 2014, area $13 \mathrm{ha}$ ). The parasitism rate was calculated: $\%$ of T. sinensis parasitism $=$ (the number of larval chambers/the number of $T$. sinensis emerged)*100. In June 2015, fresh, spring $D$. kuriphilus galls were collected from the same site and 129 galls were dissected. In dissected galls larval chambers, the number of $T$. sinensis larvae, D. kuriphilus larvae and pupae, and other parasitoid larvae were counted and parasitism rates were calculated $(\%$ of $T$. sinensis parasitism $=$ (the number of larval chambers/the number of $T$. sinensis) ${ }^{*} 100$. Parasitism rates were not calculated for the release localities in Slovenia and Hungary.

\section{RESULTS}

Slovenia, Croatia and Hungary have done a joint research of native parasitoids that have shifted to $D$. kuriphilus using the same methods since 2010 (unpublished data). This cooperation has led to joint efforts in using same methods for the raising and release of $T$. sinensis at the same time in all three countries.

\section{Croatia}

First males started to emerge 10 days after being placed at room temperatures and after two days the females started to emerge. The emergence stopped after 7 days. When put into the same tubes, males and females started to mate immediately. No mortality among males or females was noticed when they were kept at constant $14^{\circ} \mathrm{C}$ and fed with liquid honey.

The first release in Croatia was done on $11^{\text {th }}$ April 2014 in Pazin in sweet chestnut forest of 13 ha $(1,200 \mathrm{fe}-$ males/600 males). The adults emerging from the withered galls from this locality in early spring 2015 were confirmed as T. sinensis (both by DNA and morphologically), so the establishment of the population can be confirmed. The parasitism rate after the first year's release on Pazin site was $7.3 \%$. In 2015 additional 800 females $/ 400$ males were released on the same site. The parasitism rate after two year's releases calculated by dissection of galls was $75.58 \%$.

In 2015 , a total of 9,500 T. sinensis $(6,340$ mated females and 3,170 males) were released across 37 sites in continental and coastal Croatia (Figure 1). The area of release did not cover all sweet chestnut stands in Croatia. The number of females/males released varied across sites and was chosen according to the size of the forests and the intensity of infestation with D. kuriphilus. Most of the parasitoids flew away right after the release and some ovipositions were observed in the field. 


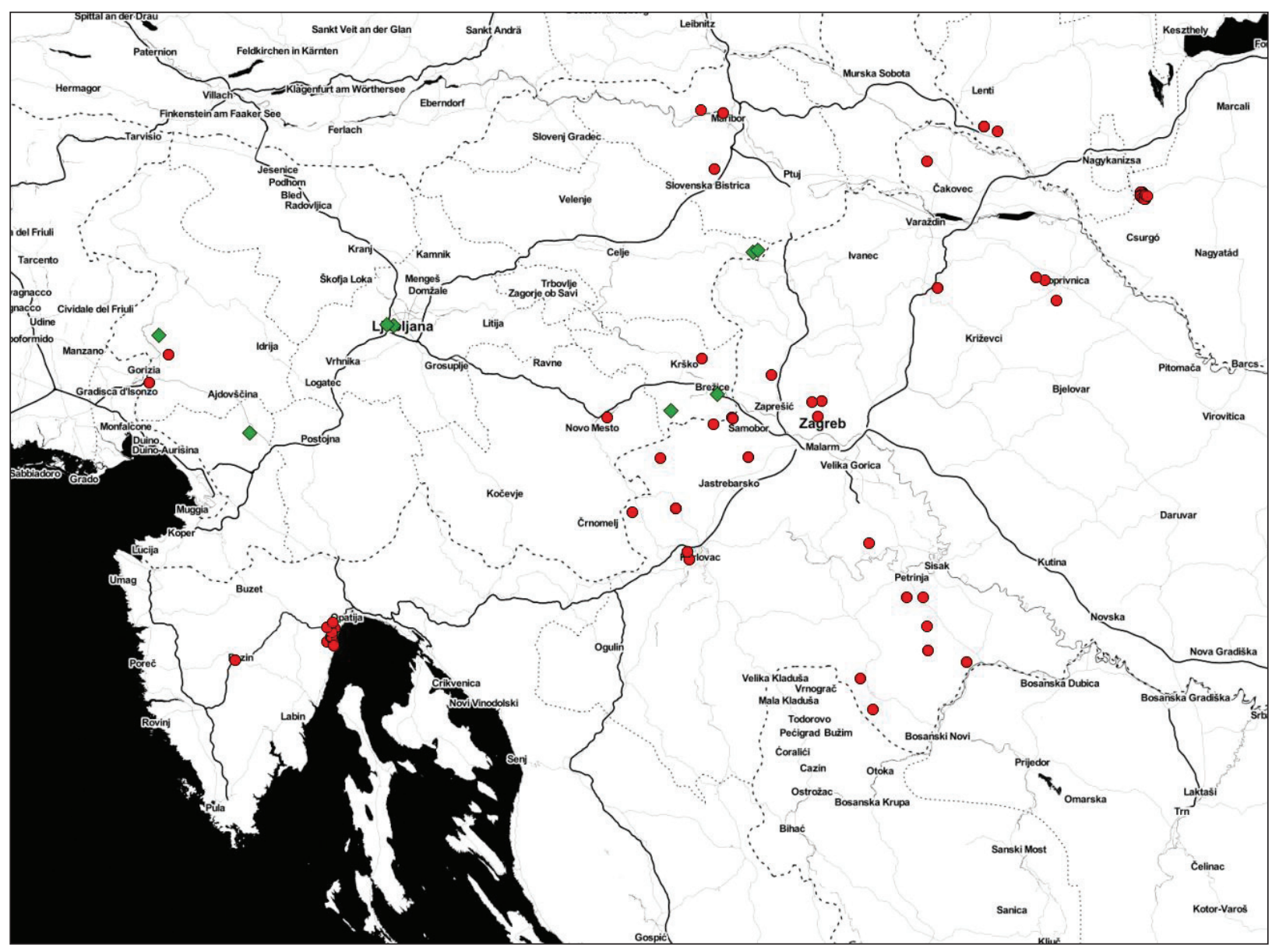

Figure 1: Release sites of Torymus sinensis in Croatia, Hungary and Slovenia (red dots) and localities (not release sites) where T. sinensis was found in 2015 (green diamonds)

\section{Hungary}

In Hungary the first release of $T$. sinensis was done in 2014 in three localities: Dobri, Kerkateskánd and Tornyiszentmiklós, in Zala County, the most south-western corner of Hungary, not far from the Slovenian border, on $9^{\text {th }}$ April. In the first experiments isolators from fine mesh were used, a branch with 50-80 buds was enclosed by $1^{\text {st }}$ April. D. kuriphilus galls started to form in the first week of April. In Dobri three isolators were put onto two chestnut trees, 20 females and 10 males were released into each of isolators on $9^{\text {th }}$ April. In Kerkateskánd 2 isolators were put out with the same number of $T$. sinensis females and males per isolator on the same day as in Dobri. Isolators were removed from the trees on $23^{\text {rd }}$ April, after all $T$. sinensis females died. In autumn, 10 galls were collected from each branch, which were earlier covered with isolators, and the dissection of collected galls showed the presence of $T$. sinensis larvae. In each of dissected galls at least one $T$. sinensis larvae was found. Later DNA analysis showed that the larvae belong to $T$. sinensis. On $26^{\text {th }}$ May 2014 T. sinensis females were released onto two trees in Kerkateskánd (50 females) and Tornyiszentmiklós (200 females). In 2015, T. sinensis was released in Zala and Somogy counties. In Zala, 100 females in Tornyiszentmiklós and 150 females in Dobri were released. In Somogy County, near Iharosberény 1,950 mated females were released on 15 points (Figure 1). The parasitism rates after the release in 2014 were not calculated for Hungary.

\section{Slovenia}

The first release of $T$. sinensis in Slovenia was on $22^{\text {nd }}$ April 2015 in chestnut orchard in Vrtojba. In two weeks 100 mated females and 50 males per location were released on six locations in Slovenia (Figure 1).

Additionally in 2015 the collecting of overwintered galls was done in March and April in natural stands of sweet chestnut on several locations in Slovenia. Morphological identification confirmed the occurrence of parasitoid T. sinensis throughout the country (Baske, Orehovica, Ljubljana, Kostanjevica, Čatež ob Savi, Log and Rogatec) (Figure 1 in green diamonds), although in 2014 galls were collected on the same locations and not a single specimen of T. sinensis was found. Genetical analyses con- 
Table 2. A selection of BLAST results at NCBI GenBank. The identity of haplotype sequences to the most similar sequences found on GenBank is displayed. Sequences within $2.7 \%$ divergence for species delimitation are shown in bold. The first most divergent taxon is shown in grey.

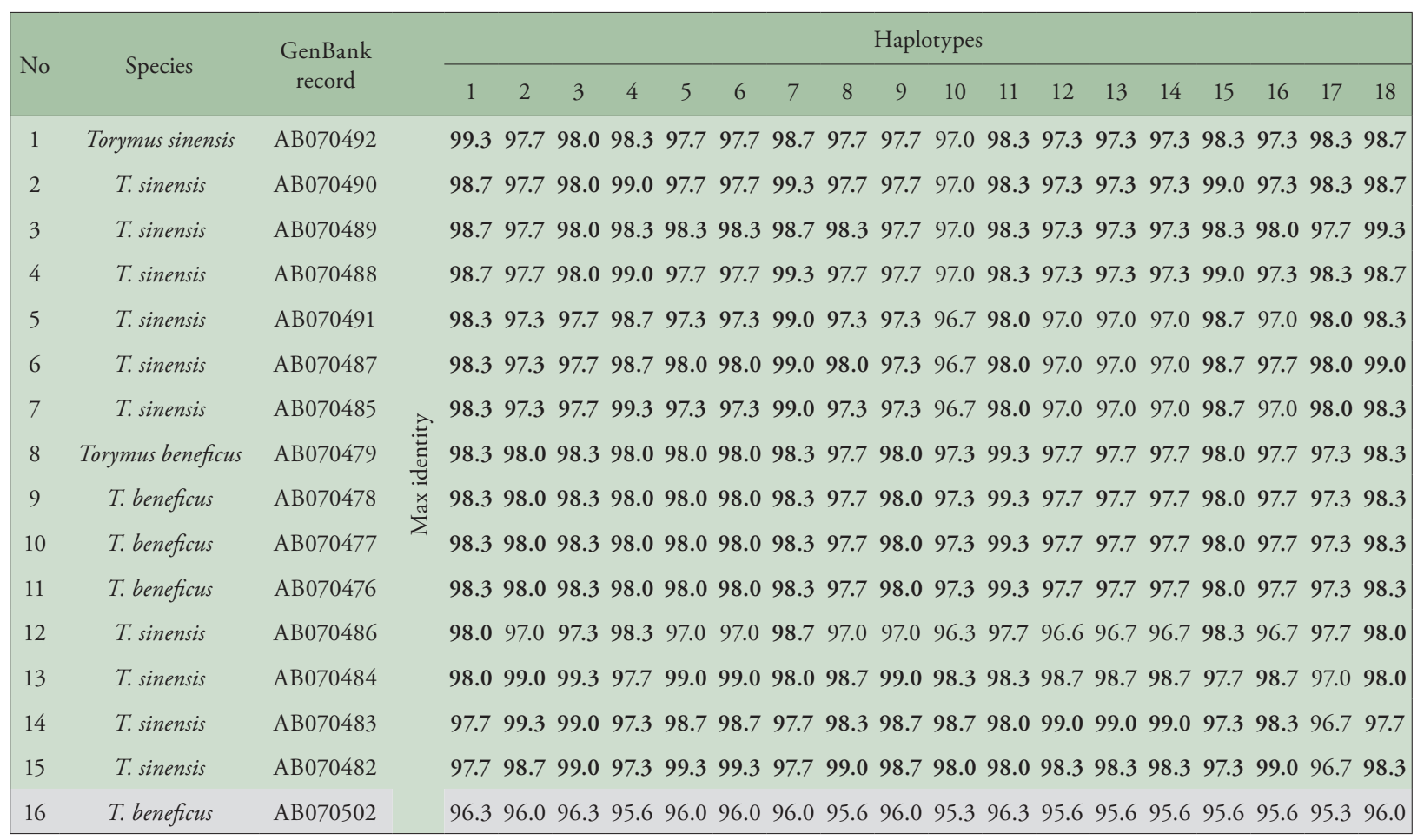

firmed the presence of $T$. sinensis in Vrtojba and Ravnica. The parasitism rates were not calculated for Slovenia because 2015 was the first year of release.

\section{Population genetic analysis}

Cladistic analysis of $68300 \mathrm{bp}$ long nucleotide sequences yielded 18 haplotype sequences based on 17 polymorphic loci. Overall haplotype diversity was $\mathrm{Hd} \pm$ (SD) 0.855 (0.028), nucleotide diversity $\pi \pm$ (SD) 0.012 (0.001) and mean number of pairwise differences was MNPD 3.554.

Ninety-five percent of intraspecific Kimura-2-parameter distances between haplotypes were found within the interval of $0.3-2.7 \%$ and the higher value was used as a cut-off to define the limit for species identification (25). Basic local alignment search (BLAST) with all determined haplotypes showed high similarity with available sequences of $T$. sinensis, and a few sequences of Torymus beneficus Yasumatsu \& Kamijo were described and deposited in NCBI GenBank by Yara (2004) (31) (Table 2).

\section{DISCUSSION}

In total 10,590 females and 5,295 males were released in Croatia, Hungary and Slovenia in 2014 and 2015. Within the area of release there are huge and unbroken complexes of sweet chestnut forests where T. sinensis will find suitable host and disperse freely in all directions. During the early years of the release, the population of $T$. sinensis will disperse slowly and, over the years, the dispersion will be faster and exponential $(6,14,17)$. Italian experience has shown that two release sites $8 \mathrm{~km}$ away from each other will see the merging of the populations of the parasitoid in 5 years, two sites $20 \mathrm{~km}$ apart in 7 years (17, 32). The minimum release per site in Croatia, Slovenia and Hungary was 100 females $/ 50$ males according to the experiences of Italian colleagues (15). Propagule pressure is a combined measure of the number of individuals of a species released (propagule size) and the number of release events (propagule number) $(33,34)$. As the number of releases or the number of individuals released increases, propagule pressure also increases. To increase the propagule pressure and the possibility of a successful establishment of $T$. sinensis populations, up to 1,200 females were released on some sites in Croatia (with additional release of 800 females on the same site) and 200 females were released again on the same site in Hungary in 2015. This has proven to be an efficient method as the population in Pazin, Croatia has been very quickly established. In the forest of an area of 13 ha after only two years parasitism rate has been $76 \%$, while similar parasitism rates have been observed on Italian sites after 6-7 years after releasing 100 females (17). Our experience with the release of a high number of females/males on one locality shows that it is possible to achieve high parasitism rates only one 
year after the release (two releases). Previous research on parasitoids in Pazin has not shown the presence of $T$. sinensis (12), so present high parasitism rate can be attributed to the release of this parasitoid species. Pazin site will be used as a first collecting site for T. sinensis in Croatia and Tornyiszentmiklós will be used in Hungary. Molecular analysis has also given unexpected results: on two sites in Slovenia (Vrtojba and Ravnica) and two sites in Croatia (Tunel Učka, Samobor) T. sinensis was identified although there was no official and registered release on these sites. Morphological identification has also shown presence of $T$. sinensis on several sites across Slovenia. This presence of $T$. sinensis could be a result of unregistered release or natural spread from Italy where the introduced parazitoid has been widely released in the last 10 years (17). This finding will only facilitate and speed up the establishment and spread of T. sinensis populations in Croatia and Slovenia as this and the released populations will merge and disperse.

According to the high similarity of obtained haplotype sequences with the COI barcode sequences of $T$. sinensis deposited in GenBank, it can be concluded that the identification of analysed specimens was positive. However, similarity with a few sequences of $T$. beneficus was also observed (Table 2). A phylogenetic similarity between these two species was already reported in eastern Asia (31, 35 ), where a late-spring strain of $T$. beneficus was found to be phylogenetically closely related to $T$. sinensis. The same author reported a higher level of hybridization between these two taxa, indicating a relatively recent speciation and a low level of genetic divergence, the fact that can complicate species delimitation even by means of molecular biology.

Prior to the release of T. sinensis, all advantages and disadvantages of the introduction of this alien biocontrol species into natural stands in Croatia, Hungary and Slovenia have been considered. The introduction of $T$. sinensis as a viable management option for biological control of D. kuriphilus with the identification, assessment and weighing up of all adverse and beneficial effects of the introduction of a biological control agent (especially an alien species) was discussed prior to the introduction (5, 9, 36, 37). Croatia, Hungary and Slovenia have taken into account all known environmental risks, as well as the benefits, and decided to release T. sinensis into natural habitats although some references point out insufficient data of performing accurate risk assessment on T. sinensis $(9,37)$. Torymus sinensis is considered specific to $D$. kuriphilus (6), but recent research has found possible shift to non-target species particularly onto oak gall wasp, $B i$ orhiza pallida (37). However, the evidence provided by the authors are too weak to make serious conclusions and further research is in need to confirm this host shift to oak gall wasps. These risks and shifts to non-target species are difficult to quantify and there is a possibility that they would be present in the $T$. sinensis range in the future.
However, all the experiences and results from Japan, the USA, Italy and France (6) have shown that $T$. sinensis is an effective biocontrol agent and that it manages to supress the populations of D. kuriphilus and the damage it makes to sweet chestnut forests and orchards. In Croatia, Slovenia and Hungary native Torymus species have shifted to D. kuriphilus (12, Matošević, Melika and Kos unpublished data) and our future research must focus on interactions between these native parasitoid species and the introduced T. sinensis. Nevertheless, we consider $T$. sinensis to be a safe and efficient biological control against D. kuriphilus, but further research on its spread, parasitism rates and possible shifts onto non-target species must be done.

Acknowledgment: The authors would like to thank Giovanni Bosio and Ambra Quacchia for their help in collecting the galls, valuable advice on the rearing and releasing of the parasitoids and numerous other helpful comments. Dinka Matošević would like to thank Blaženka Ercegovac, Anton Brenko, Zlatko Huljina for help in field and laboratory work, and Ivana Pešut and Goran Videc for recognising the importance of biological control in Croatian forestry. The project in Croatia was supported by Ministry of Agriculture, IPP programme 2014, 2015 and partially supported by „Hrvatske šume”. George Melika and Eva Kriston were supported by OTKA (Hungarian Scientific Research Fund) K101192 grant. The project in Slovenia was supported by The Administration of the Republic of Slovenia for Food Safety, Veterinary and Plant Protection.

\section{REFERENCES}

1. ROQUES A, 2010 Alien forest insects in a warmer world and a globalised economy: impacts of changes in trade, tourism and climate on forest biosecurity. New Zealand Journal of Forestry Science, 40 Suppl: 77-94

2. ROQUES A, KENIS M, LEES D, LOPEZ-VAAMONDE C, RABITSCH W, RASPLUS J Y, ROY D 2010 Alien terrestrial arthropods of Europe. BioRisk, 4, Special Issue

3. MATOŠEVIĆ D, PAJAČ ŽIVKOVIĆ I 2013 Strane fitofagne vrste kukaca i grinja na drvenastom bilju u Hrvatskoj. Šumarski list 137(3-4): 191-203

4. BRUSSINO G., BOSIO G, BAUDINO M, GIORDANO R, RAMELLO F, MELIKA G. 2002 Nuovo cinipide galligeno in Piemonte. Pericoloso insetto esotico per il castagno europeo. L'Informatore Agrario 37: 59-61

5. EFSA 2010 Risk assessment of the oriental chestnut gall wasp, Dryocosmus kuriphilus for the EU territory and identification and evaluation of risk management options. EFSA Journal. 8 (6): 1-114

6. MATOŠEVIĆ D, QUACCHIA A, KRISTON É, MELIKA G 2014 Biological Control of the Invasive Dryocosmus kuriphilus (Hymenoptera: Cynipidae) - an Overview and the First Trials in Croatia. South-east Eur for 5 (1): 3-12 DOI: http://dx.doi.org/10.15177/seefor.14-05

7. AEBI A, SCHÖNROGGE K, MELIKA G, ALMA A, BOSIO G, QUACCHIA A, PICCIAU L, ABE Y, MORIYA S, YARA K, SELJAK G, STONE GN 2006 Parasitoid recruitment to the globally invasive chestnut gall wasp Dryocosmus kuriphilus. In: Ozaki K, Yukawa J, Ohgushi T, Price PW (eds) Ecology and evolution of galling 
arthropods and their associates, Springer-Verlag, Tokyo, 103-121 http://dx.doi.org/10.1007/4-431-32185-3_9

8. AEBI A, SCHÖNROGGE K, MELIKA G, QUACCHIA A, ALMA A, STONE G N 2007 Native and introduced parasitoids attacking the invasive chestnut gall wasp Dryocosmus kuriphilus. OEPP/EPPO, Bulletin 37, 166-171

9. GIBBS M, SCHÖNROGGE K, ALMA A, MELIKA G, QUACCHIA A, STONE G N, AEBI A 2011 Torymus sinensis: a viable management option for the biological control of Dryocosmus kuriphilus in Europe? BioControl 56 (4): 527-538

10. SANTI F, MAINI S $2012 \mathrm{Il}$ cinipide galligeno del castagno e i suoi nemici naturali. Rivista di Frutticoltura e di Ortofloricoltura 74: 64-69

11. QUACCHIA A, FERRACINI C, NICHOLLS J A, PIAZZA E, SALADINI M A, TOTA F, MELIKA G, ALMA A 2012 Chalcid parasitoid community associated with the invading pest Dryocosmus kuriphilus in north-western Italy. Insect Conserv Diver 6 (2): 114 123

12. MATOŠEVIĆ D, MELIKA G 2013 Recruitment of native parasitoids to a new invasive host: first results of Dryocosmus kuriphilus parasitoid assemblage in Croatia. Bull Insectology 66 (2): 231-238

13. FRANCATI S, ALMA A, FERRRACINI C, POLLINI A, DINDO M L 2015 Indigenous parasitoids associated with Dryocosmus kuriphilus in a chestnut production area of Emilia Romagna (Italy). Bull Insectology 68 (1): 127-134

14. MORIYA S., SHIGA M., ADACHI I., 2003. Classical biological control of the chestnut gall wasp in Japan In: Van Driesche R. G (ed) Proceedings of the 1st international symposium on biological control of arthropods Honolulu, USA. 407-415

15. QUACCHIA A, MORIYA S, BOSIO G, SCAPIN I, ALMA A 2008 Rearing, release and settlement prospect in Italy of Torymus sinensis, the biological control agent of the chestnut gall wasp Dryocosmus kuriphilus. BioControl 53 (6): 829-839 http://dx.doi.org/10.1007/s10526-007-9139-4

16. COOPER W R, RIESKE L K 2011 A native and an introduced parasitoid utilize an exotic gall-maker host. BioControl 56 (5): 725-734 http://dx.doi.org/10.1007/s10526-011-9350-1

17. BOSIO G, ARMANDO M, MORIYA S 2013 Verso il controllo biologico del cinipide del castagno. L'Informatore Agrario 14: 60-64

18. BOROWIEC N, Thaon M, BRANCACCIO L, WAROT S, VERCKEN E, FAUVERGUE X, RIS N, MALAUSA J C 2014 Classical biological control against the chestnut gall wasp Dryocosmus kuriphilus (Hymenoptera, Cynipidae) in France. Plant Protection Quaterly 29 (1): 7-10

19. MELIKA G, MATOŠEVIĆ D, KOS K, BOSIO G, KRISTON E, KRIZBAI L, BOZSÓ M, CSÓKA G 2013 Native parasitoids attacking the chestnut gallwasp, Dryocosmus kuriphilus (Hymenoptera: Cynipidae), across Italy - Slovenia - Croatia - Hungary. In Book of Abstracts of II. European Congress of Chestnut, Debrecen, Hungary, $\mathrm{p} 45$

20. FOLMER O, BLACK M, HOEH W, LUTZ R, VRIJENHOEK R 1994 DNA primers for amplification of mitochondrial cytochrome c oxidase subunit I from diverse metazoan invertebrates. Mol Mar Biol Biotech 3(5), 294-299

21. STRANGI A, PEVERIERI G S, ROVERSI P F, 2013 Managing outbreaks of the citrus long-horned beetle Anoplophora chinensis (Forster) in Europe: molecular diagnosis of plant infestation. Pest Manag Sci 69: 627-634 http://dx.doi.org/10.1002/ps.3416
22. HALL T A, 1999 BioEdit: a user-friendly biological sequence alignment editor and analysis program for Windows 95/98/NT. Nucl Acid S 41, 95-98

23. LIBRADO P, ROZAS J, 2009 DnaSP v5: A software for comprehensive analysis of DNA polymorphism data. Bioinformatics 25, 451-1452 http://dx.doi.org/10.1093/bioinformatics/btp187

24. ALTSCHUL S F, MADDEN LT, SCHÄFFER A A, ZHANG J, ZHANG Z, MILLER W, LIPMAN D J 1997 Gapped BLAST and PSI-BLAST: a new generation of protein database search programs. Nucleic Acids Res 25: 3389-3402

25. MEIER R, KWONG S, VAIDYA G, PETER K L 2006 DNA Barcoding and Taxonomy in Diptera: a Tale of High Intraspecific Variability and Low Identification Success. Syst Biol 55: 715-728 http://dx.doi.org/10.1080/10635150600969864

26. TAMURA K, STECHER G., PETERSON D, FILIPSKI A, KUMAR S 2013 MEGA6: Molecular Evolutionary Genetics Analysis version 6.0. Mol Biol Evol 30: 2725-2729 http://dx.doi.org/10.1093/molbev/mst197

27. CLEMENT M, POSADA D, CRANDALL K 2000 TCS: a computer program to estimate gene genealogies. Mol Ecol9, 1657-1660 http://dx.doi.org/10.1046/j.1365-294x.2000.01020.x

28. CRANDALL K A, TEMPLETON A R 1993 Empirical tests of some predictions from coalescent theory with applications to intraspecific phylogeny reconstruction. Genetics 135: 959-969

29. ASKEW R R, MELIKA G, PUJADE-VILLAR J, SCHÖNROGGE K, STONE G N, NIEVES-ALDREY J L 2013 Catalogue of parasitoids and inquilines in cynipid oak galls in the West Palaearctic. Zootaxa, 3643 (1): 1-133

30. GRAHAM M W R D V, GIJSWIJT M J 1998 Revision of the European species of Torymus Dalman (s.lat.) (Hymenoptera: Torymidae). Zoologische Verhandelingen Leiden 317: 3-202

31. YARA K 2004 Relationship between the introduced and indigenous parasitoids Torymus sinensis and T. beneficus (Hymenoptera: Torymidae), as inferred from mt-DNA (COI) sequences. Appl Entomol Zool 39: 427-433 http://dx.doi.org/10.1303/aez.2004.427

32. MINISTERO DELLE POLITICHE AGRICOLE, AND ALIMENTARI E FORESTALI ITALIA 2010 Technical Reference for the Implementation of the Biological Control of Chestnut with Torymus Sinensis (in Italian)

33. DAVIS M A 2009 Invasion biology. Oxford University Press, Oxford, UK

34. LOCKWOOD J, HOOPES M, MARCHETTI M 2006 Invasion Ecology. 1st ed. Blackwell Publishing Ltd, Malden, MA, USA

35. YARA K 2014 Interaction between Torymus sinensis (Hymenoptera: Torymidae) and T. beneficus, Introduced and Indigenous Parasitoids of the Chestnut Gall Wasp Dryocosmus kuriphilus (Hymenoptera: Cynipidae). JARQ 48 (1) 35-40 http://dx.doi.org/10.6090/jarq.48.35

36. QUACCHIA A, MORIYA S, ASKEW R, SCHÖNROGGE K 2014 Torymus sinensis: biology, host range and hybridization. Acta Hortic 1043:105-111 http://dx.doi.org/10.17660/ActaHortic.2014.1043.13

37. FERRACINI C, FERRARI E, SALADINI M A, PONTINI M, CORRADETTI M, ALMA A 2015 Non-target host risk assessment for the parasitoid Torymus sinensis. Biocontrol http://dx.doi.org/10.1007/s10526-015-9676-1 